\title{
Connecting an Urban Mosaic: Open Spaces and Sustainable Places of Belgrade
}

JEANETTE BURMAN \& SASHA TSENKOVA

University of Calgary

Following a rapid transition to markets, democracy and private enterprise, Serbia's capital Belgrade is emerging as a 'global city', but this ambition is coming at a cost to the environment and a loss of sense of place for its people. Diverse identities and changing values over time are being challenged as the city transitions out of a complex socialist past into a pervasively global economy, which by definition challenges locally embedded hybridity of place and puts strain on sustainable growth. Open spaces are required for city residents to live, work, and move efficiently, making the use, access, and ecological integrity of open spaces a city-wide priority. The dependence and attachment of city residents to these spaces provides an ideal baseline for analysis of different open space typologies integral to the urban fabric defining a wide range of urban resiliency strategies. This people-centered approach, coupled with an understanding of the contemporary and historical significance of open spaces, raises the question of how to improve and connect such forms to the urban fabric while respecting place identity in response to post-socialist spatial change. Our case studies inspect the socialist landscapes of public open spaces in New Belgrade as they have transformed in a contemporary context. Other case studies demonstrate the systematic loss of open space taken over by private informal housing on one hand, but also as people-driven initiatives reclaiming the urban landscape on the other. Using fresh empirical evidence and case study analysis at the neighborhood scale, this research employs an open space typology of resiliency in place for a connected urban mosaic of post-socialist Belgrade. The analytical framework draws on existing urban research in the context of post-socialist transition and advances a design matrix to analyze open space forms for connectivity in relation to place and sustainability.

\subsection{INTRODUCTION}

Serbia's capital city Belgrade is emerging out of a socialist past and into a global future. Our research looks at the ability of place and open spaces to assist in a sustainable response to critical urban transitions facing Belgrade. The post-socialist transition indicates a rapid move to democracy, market economies, and decentralization of government controls, which have transformative implications for public and private interests in urban and peri-urban spaces. The result is what Tsenkova and Nedovic-Budic [1] refer to as an urban mosaic, subject to diverse spatial transformations. In this regard, Belgrade provides a unique and ideal context of the dramatic shifts of past socialist narratives in a global future. Most notably, a spectrum of informal housing developments has appropriated space from the public realm, fragmenting the urban fabric. Meanwhile public open spaces of the Socialist era have fallen into disrepair despite their heavy use and have been criticized for lacking in human scale [2-4]. These 'top-down' institutional designs differ from 'bottom-up' designs of Belgrade's informal/formal subdivisions, providing an opportunity for a comparative analysis at the neighborhood scale. This research proposes that the resiliency of the greater Belgrade Metropolitan Area (BMA) to post-socialist spatial change is interconnected with diverse values and meanings found within typologies of open spaces. Additionally, that the sustainable development of the BMA is dependent on resiliency parameters where quality of place matters. We develop a design tool for analyzing the resiliency of neighborhoods as open spatial entities while being mindful of place in the post-socialist context. The tool identifies 
place elements in relation to open space typologies and resiliency parameters. Furthermore, we utilize this tool in examples of spatial case studies of Belgrade, including New Belgrade and informal subdivisions. The result is a conceptual connected urban mosaic that promotes the sustainable development and place resiliency of the BMA within a defined methodological approach.

\subsection{THEORETICAL APPROACHES}

As a capital city Belgrade has been the center of economic transport, cultural exchange, and migration since antiquity. In recent years the city has faced challenges affecting urban sustainable growth including access to and the use of open spaces due to post-socialist transition. In Kiril Stanilov's [5] edited book The Post-socialist City, authors make compelling cases as to the loss of public open space in post-socialist Eastern European cities. Restitution of government owned and controlled land to private ownership has fundamentally limited both government and urban planners from protecting public interests in access to open space, a previous hallmark and asset to socialist planning system, as well as created challenges to sustainable urban development [6]. For example, development patterns have resulted in urban sprawl [7] and smaller urban centers are faced with identity crisis as urban spaces become infiltrated by global privatization [8]. Other research calls for contextual strategic planning in uniting both private and public interests and investments in post-socialist spatial transformations [9]. In Belgrade the private appropriation of open space for informal housing developments is a significant indicator of challenges posed by the post-socialist transition. Research shows that the widespread diversity of informal settlements is an unintended consequence of the post-socialist transition often manifested through the illegal or semi-legal occupation of open spaces [10]. The diversity of these settlements constitutes a spectrum of informality and community driven responses to spatial change. Tsenkova's [11] typology of informality indicates that informal subdivisions are built on high quality spaces, have better quality in construction, and are likely to be legalized and incorporated into the city's master plan. The informal/formal structure of Belgrade consists of informal settlements, as satellites that have infused throughout the urban fabric amongst contemporary Belgrade, Old Belgrade, as well as New Belgrade. One of these settlements, Kaluđerica, was integrated into the city's master plan due to its vastness, with a population of over 50, 000 residents [12]. The lack of basic services and building safety as well as make-shift infrastructure have been topics of concern in literature, policy, and NGOs, see [1, 10, 12]. However, the open spatial resiliency of these settlements is largely unexplored. In contradiction to the 'bottom-up' developments of informal Belgrade, the socialist era development New Belgrade represents a 'top down' approach to building that also has unique place and space relations, where open spaces are heavily used [3]. However, New Belgrade spaces have been criticized for, like other institutional designs, lacking in human feeling, care, and scale [2, 3]. Additionally, informality including Romani squatter settlements, have faced removal from government officials for multiple reasons including illegal permits and unsafe living conditions [13]. Recent research also discusses renewed investment and development in New Belgrade [14, 15], but the significance of open spaces in New Belgrade's future is relatively unexplored.

\subsection{OPEN SPACE \& SUSTAINABLE PLACE}

Significant to this research is the important role open spaces play in sustainable cities. Drawing on substantial literature in sustainable planning, Al-Hagla [16] develops a typology itemizing sustainability objectives, goals, and parameters of open spaces that empirically evaluate the sustainable performance of communities and neighborhoods. However, 'place' is indicated within these attributes without distinct values. In a strategic planning approach, Healey [17] indicates 6 criterion for conceptualizing place and space but warns of the tendency to borrow localities in evaluating and does not employ a typology of space. Stanley et. al. [18] build upon Al-Hagla [16] by normalizing open space typologies through function at city, neighborhood, and residential scales. Their developed green, grey, and grey/green typology provides a neutrality of space subject to dialectic from 'top-down' forces of planners or government competing with 'bottom-up' forces of society or a community [18]. In terms of the people centered

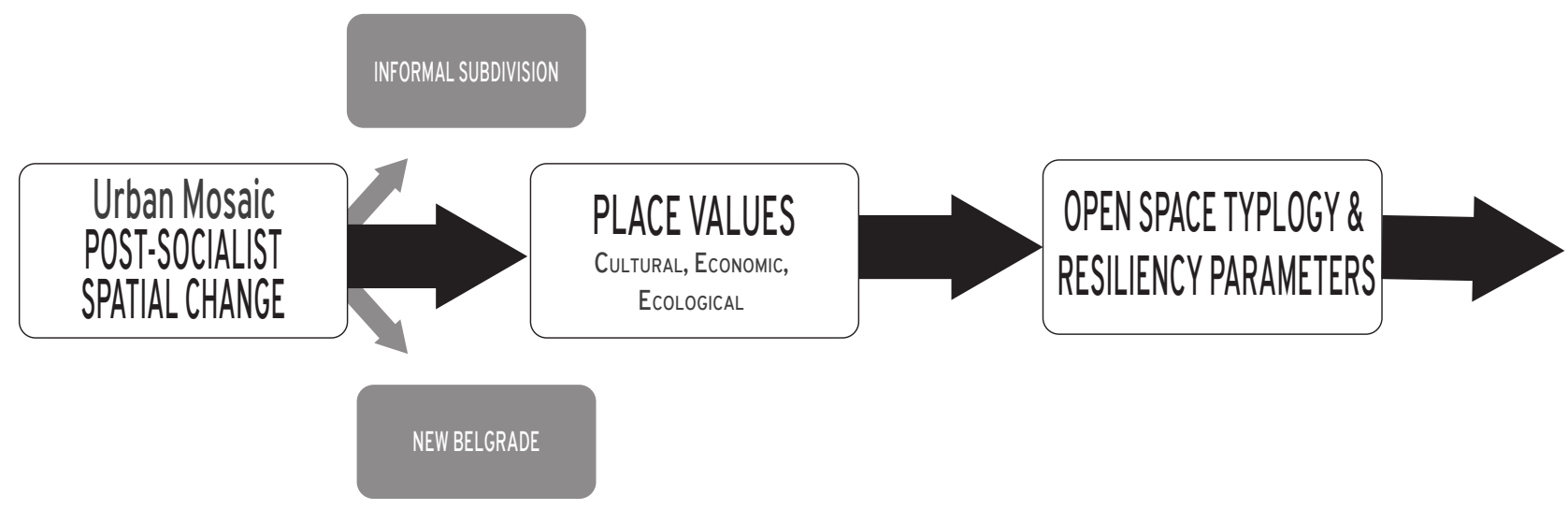

Figure 1: Framework for a Connected Urba 


\begin{tabular}{|c|c|c|c|}
\hline Place Values & z & 山 & 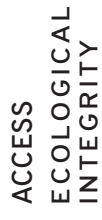 \\
\hline \multicolumn{4}{|l|}{ CULTURAL } \\
\hline Realizing an iconography \& iconology & $\square \square \square$ & $\square$ & $\square \square$ \\
\hline Authentic historical significance & $\square \square \square$ & $\square$ & $\square \square$ \\
\hline Social wellbeing of space & $\square \square \square$ & $\square$ & $\square \square$ \\
\hline \multicolumn{4}{|l|}{ ECONOMIC } \\
\hline Providing services and resources & $\square \square \square$ & $\square$ & $\square \square$ \\
\hline Enhancing community \& social networks & $\square \square \square$ & $\square$ & $\square \square$ \\
\hline Increasing public realm & $\square \square \square$ & $\square$ & $\square \square$ \\
\hline \multicolumn{4}{|l|}{ ECOLOGICAL } \\
\hline Opportunities to engage with nature & $\square \square \square$ & $\square$ & $\square \square$ \\
\hline Learning from nature & $\square \square \square$ & $\square$ & $\square \square$ \\
\hline Enabling ecosystem services & $\square \square \square$ & $\square$ & $\square \square$ \\
\hline
\end{tabular}

Figure 2: Resiliency in Place and Open Space Design Tool

approach of this research, the concept of place can further engage the dialogue. Agnew [19] defines place as having three distinct categories of geographic location, descriptive setting-including stylistic or aesthetic-and sense of place, or the meaningful experience of space. In this regard, Beatley and Manning [20] argue for an ecology of place to include environmental, economic, and community aspects of sustainable planning and development in the urban context. Open spaces enable sociological and ecological values in urban environments [21], as well as provoke inclusive identities when addressed in strategic spatial planning [17]. Several authors have also approached place through the ecological/environmental perspective including the ecological health of space in performing supporting, regulating, and provisioning ecosystem services, of which place may be a benefactor, see [22, 23]. Form and function relations that are unique or distinct in their iconography or iconology of space and have cultural significance provide stylistic and aesthetic elements as well as sense of place, see [24-27]. And finally economic values of place can contribute to increased wellbeing through services, resources, and prosperity, often through localized and equitable initiatives [20].

This deeper context of sustainability indicates responsiveness to critical changes in the urban fabric to include human experience. Resiliency represents such strategies that typify 'bottom-up' approaches surrounding adaptation to crisis or critical systems changes [28]. The post-socialist transition has created such critical systems changes that have resulted in spatial change. Public access to open space is crucial in the democratic transition as public open space is a democratic resource that through occupation constitutes a form of citizenship [29]. In these spaces, citizens can create meaningful space by "expressing their attitudes, asserting claims, and using it for their own purposes" [30]. In terms of environmental impact of green spaces, Chetkiewicz et. al. [31] analyze land-use corridors for habitat selection and movement to connect fragmented landscapes; and Johan Colding [32] advocates for Ecological Land-use Complementation (ECL) for supporting biodiversity and ecological responsiveness in urban settings. In addition, critiques of sustainability as lacking operational device [33] and requiring a more clear definition [20] may apply to the more ephemeral descriptions of place in this research, thus requiring an astute method for dissemination.

\subsection{FRAMEWORK}

This research argues that the diverse contexts of place and space that encompass Belgrade's complex contemporary history are important in the resiliency of open spaces in the post-socialist transition. The role of open spaces in sustainable development has been approached in the research yet the role of place in open spaces has often been overlooked. Firstly, our conceptual framework, as seen in Figure 1, indicates that spatial change in post-socialist Belgrade is a diverse urban mosaic, which at the neighborhood scale can be exemplified in socialist era developments and informal subdivisions. Secondly, place attributes are introduced as a contextual component to sustainable space to include cultural, economic and environmental/ecological values derived from literature. Cultural includes realizing an iconography and iconology of space, authenticity in historical significance, and social wellbeing of space, see [34-36]. Economic includes providing services and resources, enhancing community and social networks, and increasing the public realm, see [20,37]. Finally, ecological, or environmental, includes opportunities to engage 


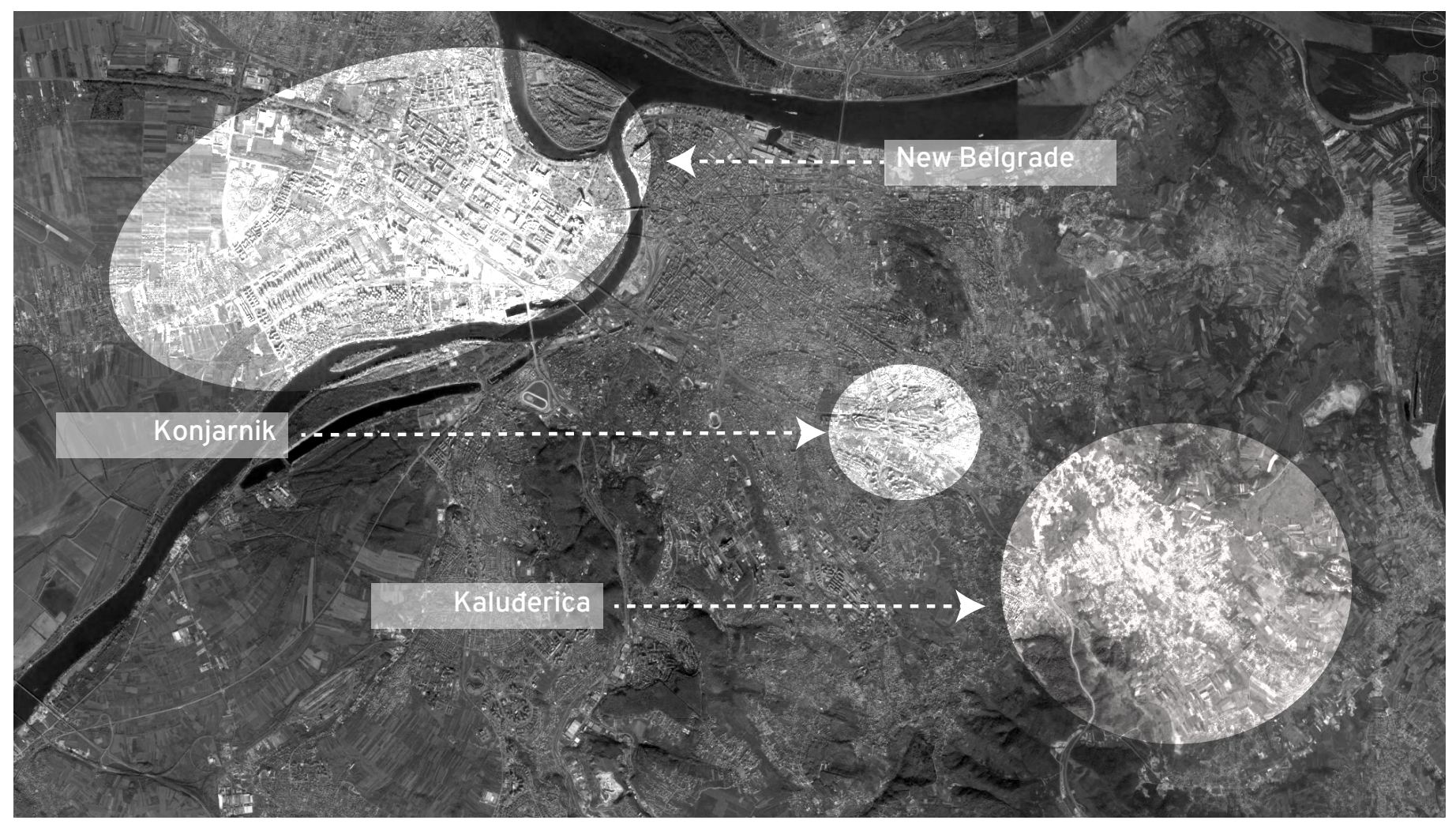

Figure 3: Map of Case Studies

with nature, learning from nature, and enabling ecosystem services, see [23].

From this perspective, the open space typology employed is a green, grey, and grey/green derived from Al-Hagla [16] and Stanley et. al. [18]. This typology is assessed in relation to resiliency parameters that include the use, access, and ecological integrity of space in relation to cultural, ecological, and economic place values. The use of space can be defined as the ability to occupy space for personal and public uses, see [16, 38]; the access of space can be defined as the ability to travel to spaces and enhance personal or community networks within the public realm, see $[38,39]$; the ecological integrity of open space can be defined as the ability of open spaces to perform ecosystem services while limiting the impact of human intervention through resource management and maintenance, $[16,38]$. To aid in analysis, we have developed a design tool as seen in Figure 2. Although our methods focus on the neighborhood scale, we believe that they are transferrable to the city scale as well as outside of the post-socialist context.

\subsection{METHODOLOGY}

This research employs a case study approach in the collection of empirical evidence as well as primary and secondary data at the neighborhood scale $[40,41]$. Open spatial typologies are identified for both formal socialist and informal post-socialist developments. Observational data for case studies was collected using Google Earth as well as secondary data from recent reports and literature. Google Earth imaging is used due to site visit limitations.
This approach has limited the ability for a complete spatial survey. Subsequently, the research identifies examples of distinct forms at both neighborhood and city scales as opposed to a complete inventory of all existing spatial forms. For each case, the design matrix is employed to analyze resiliency in place and open space for possible interventions. Three distinct case studies have been selected to represent the diverse informal/formal relations of post-socialist spatial transformations in Belgrade. The socialist development New Belgrade, informal subdivision Kaluđerica, and the formal socialist/informal post-socialist Konjarnik are the three selected cases as seen in Figure 3.

\subsection{NEW BELGRADE}

With a population of over 200,000 residents the large-scale socialist era development of New Belgrade sits west of the Sava River and Old Belgrade. The district consists of controlled grid planning schemes of several neighborhood blocks with modernist high-rise housing complexes of an institutional era juxtaposed with highly used open spaces. The New Belgrade plan was adapted from the Athens Charter, authored by Le Corbusier amongst others, beginning construction in 1948. A significant differentiating factor between New Belgrade and the Athens Charter plan was the central location of Government [42] . According to Forsyth and Crewe [24] the Athens Charter "is a vision of top-down local and regional planning that deals with the coordination of what it terms habitation, leisure, work, and traffic-the main issues of land in a city". However, challenges are seen in resulting spatial forms that lack in human scale, use value, and equality in access for an 'aesthetic 


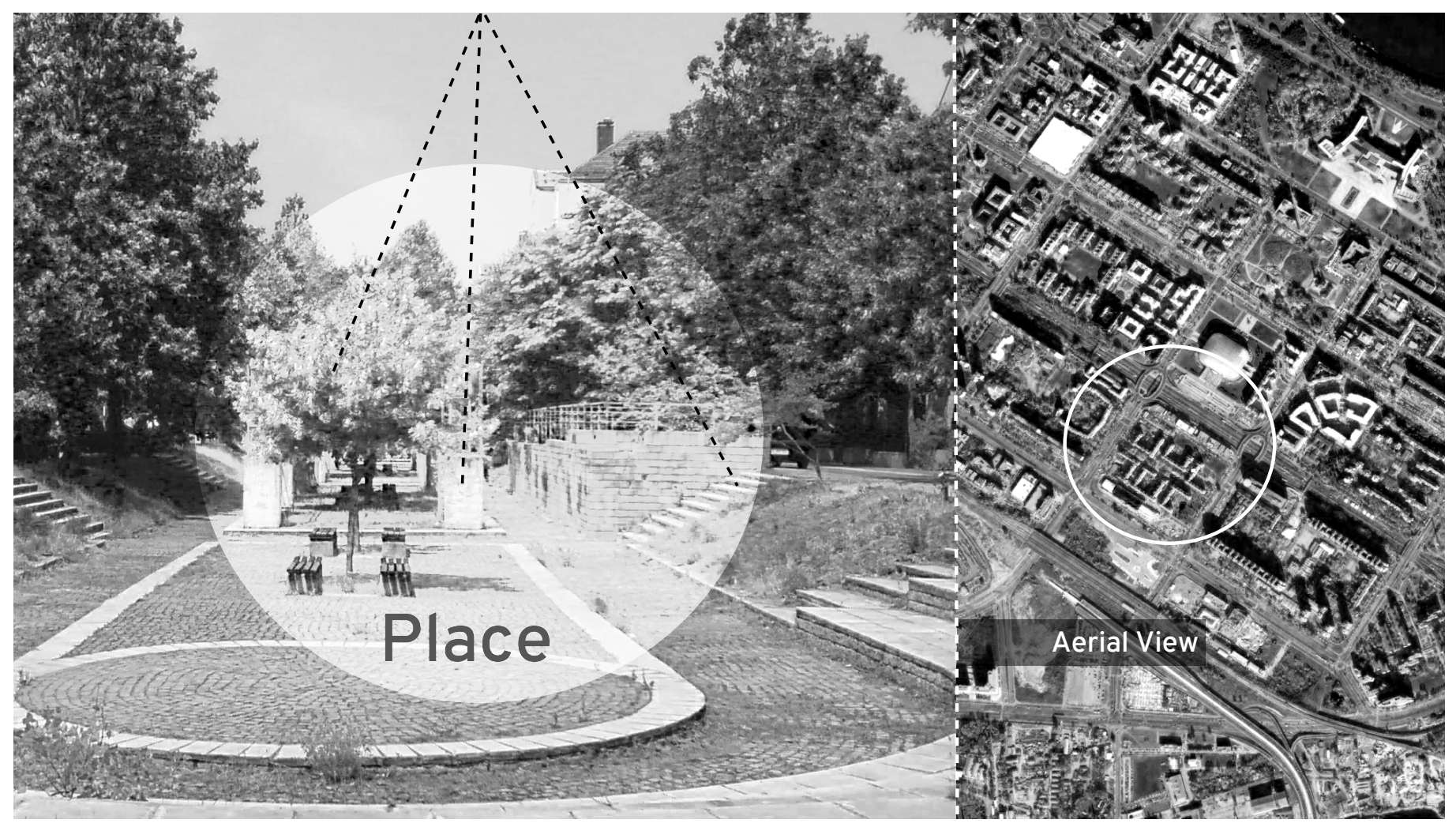

(a) New Belgrade - Grey/Green Open Space

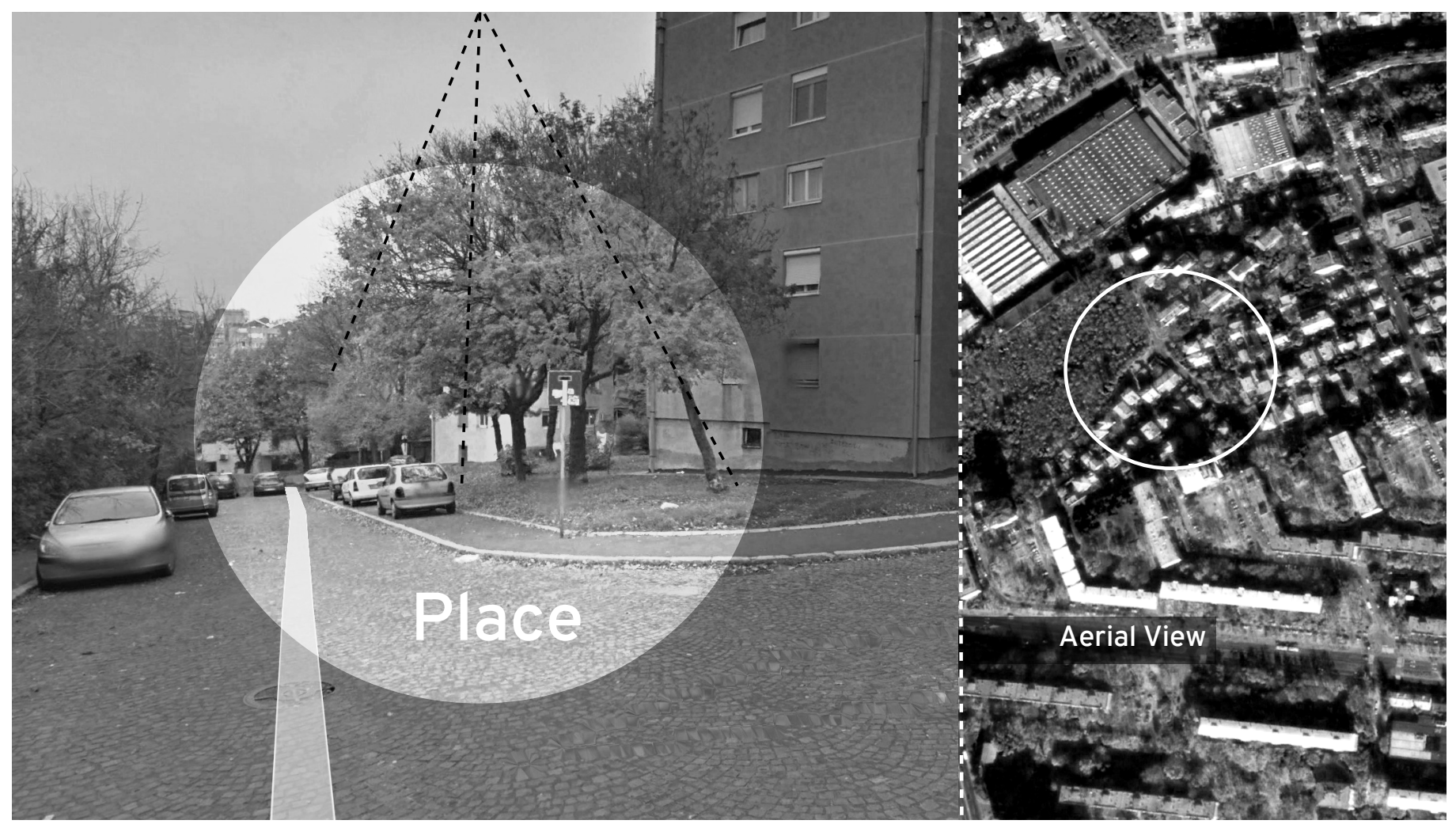

(b) Konjarnik - Grey Open Space 


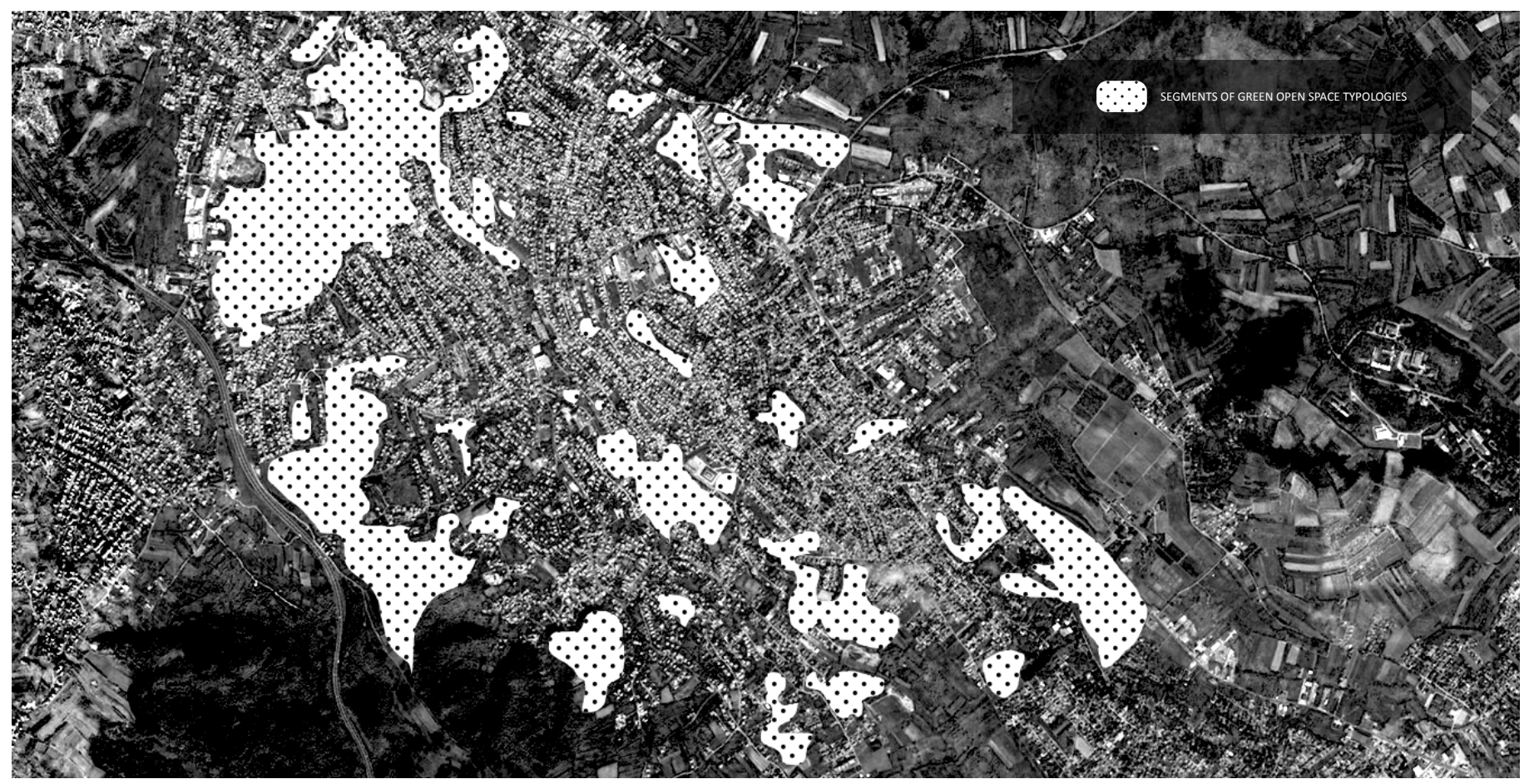

Figure 5: Case Study Example Kaluđerica

and architectural continuity' [3]. Public open space in New Belgrade is also exclusionary to marginalized populations, such as Romani populations. The forced removal of Romani informal housing has resulted in what Bobic [13] describes as spatial violence. Yet, the diversity of place that New Belgrade provides the post-socialist urban fabric has also been heralded as post-modern and in this sense universal for the post-industrialist city [2]. Using Google Earth and the design tool, the research has isolated the neighborhood originally called Block 21 within New Belgrade for place analysis. As seen in Figure 4 (a), grey/green space has been selected for analysis. From this example, the research proposes that employing the design tool can focus planning and design on place values of ecological place and address use parameters of the selected form for potential interventions. Contextually, opportunities for ecological care reintegrate personal investment in the space and re-aligns with public use values of the socialist regime in post-socialist Belgrade. From a resiliency perspective, an intervention could improve both the cultural and ecological values of place in response to the post-socialist transition.

\subsection{KONJARNIK}

The Konjarnik district is located in the southeast central region of the BMA, between two major transport highways and next to historical Šumice Park-a small remaining portion of a network of natural parks that existed prior to WWI. The name Konjarnik means 'horse grazing area' defining the function of the space as horse grazing and breeding grounds after the Second World War. Expanding development of the 1960s and 1970 s created spatial forms similar to New Belgrade in most of the district, yet informal development still managed to precipitate most likely due to the high quality of land and central location [11, 12]. The research has identified a streetscape using Google Earth and uses the design tool for analysis. As seen in Figure 4 (b), the walkway faces common parking issues seen throughout the BMA, where the private space of the vehicle informally occupies a public walkway, limiting pedestrian access. Using the design tool, the research proposes to address access parameters in relation to cultural place values to intervene.

\subsection{KALUDERICA}

Kaluđerica is a satellite settlement of with a population of nearly 50,000 located in the southeast periphery of the BMA. One the largest informal satellite settlements in Eastern Europe, its magnitude was impossible for planning authorities to ignore, allowing residents to negotiate land ownership, registration in the cadastre and access to public electricity, water, and transportation services [12]. Self-made houses in close proximity to each other with distinct and similar use of materials reflect more of a traditional vernacular of pre-socialist architecture in Belgrade, where sharing semi-private courtyards was common and materiality was consistent [42]. The sprawling neighbourhood has developed over time to include elementary schools, medical facilities, open markets, and shopping centers. Using Google Earth, a variety of green open space forms have been identified in Kaluđerica for analyzing the larger neighbourhood scale. As seen in Figure 5, the green typologies of open space forms appear fragmented throughout the district, with larger agricultural forms dominating the southern periphery.

Using the research design tool, practitioners on the ground level could focus on resiliency parameters of access and economic place values to begin with while engaging other dimensions through 
the process of design. For example, providing alternate modes of transportation such as cycling routes, grey spaces, between these green spaces as well as promoting the ecological integrity of the new grey spaces through green space corridors will engage multiple resiliency parameters and place values when using the design tool in practice.

\subsection{CONCLUSION}

By examining formal and informal open space relations at the neighborhood scale, this research has provided operational guidelines and examples of resiliency in place to address post-socialist spatial change in Belgrade. As the ecological integrity, use, and access of space is addressed within the provided parameters, open spaces activate place elements for increased cultural, economic, and ecological/environmental space engagement. The results show that indeed open spaces are vital components of the neighborhood as a spatial entity and the ability for these spaces to respond to critical systems changes of the post-socialist transition can prove useful in design and planning initiatives. Furthermore, the research results indicate that green, grey, and grey/green open spatial forms in the public realm are commonplace and normative, supporting Stanley et. al. [18] results. One inherent weakness of the research is a reliance on spatial data using Google Earth, which limits the ability for real time and place analysis. However, the design tool developed could provide equal guidance in more direct and place-based research at the ground level than the current paper allows. In this respect, the results indicate opportunities for further research at the city and residential scales whereby pre-existing examples of spatial interventions in Belgrade could assist in final decisions. In terms of connecting the urban mosaic, the research has proposed and analyzed both formal and informal neighborhoods for space in place interventions, thus connecting the diverse contexts of the Belgrade Metropolitan Area as spatial narratives in a transitioning and an increasingly global future.

\section{ENDNOTES}

1. Tsenkova, S. and Z. Nedovic-Budic, eds. The Urban Mosaic of Post-Socialist Europe: Space, Institutions and Policy. 2006, Springer: New York: New York.

2. Hirt, S., Landscapes of postmodernity: Changes in the built fabric of Belgrade and Sofia since the end of socialism. Urban Geography, 2008. 29(8): p. 785-810.

3. Topalović, M., New Belgrade: The modern city's unstable paradigms, in Belgrade. Formal/informal: A research on urban transformation, E.S. Basel, Editor. 2012, Scheidegger \& Spiess: Zürich. p. 128-239.

4. Wallace, E.C., A framework for change: Understanding the phenomenon of informal housing settlements in Tirana(Albania) and Belgrade(Serbia), in Environmental Design. 2006, University of Calgary: Calgary, Alberta Canada. p. 134.

5. Stanilov, K., ed. The Post-socialist City. The GeoJournal Library, ed. W. Tietze. Vol. 92. 2007, Springer: Dordrecht, The Netherlands.

6. Stanilov, K., Urban planning and the challenges of post-socialist transformation, in The Post-Socialist City, K. Stanilov, Editor. 2007, Springer: Dordrecht, The Netherlands.

7. Hirt, S. and K. Stanilov, The perils of post-socialist transformation: residential development in sofia, in The Post-socialist City, K. Stanilov, Editor. 2007, Springer: Dordrecht, The Netherlands. p. 215-244.

8. Dimitrovska Andrews, K., B. Mihelič, and I. Stanič, The post-socialist urban retructuring of Ljuljana: Strengthening Identity, in The Post-Socialist City, K.
Stanilov, Editor. 2007, Springer: Doerdecht, The Netherlands. p. 427-445.

9. Tsenkova, S., Urban futures: Strategic planning in post-socialist Europe, in The Post-Socialist City, K. Stanilov, Editor. 2007, Springer: Dordrecht, The Netherlands. p. 447-469.

10. Tsenkova, S., Housing policy reforms in post-socialist Europe: Lost in transition. 2008: Springer Science \& Business Media.

11. Tsenkova, S., Urban planning and informal cities in southeast Europe. Journal of Architectural and Planning Research, 2012. 29(4): p. 292.

12. Tsenkova, S., Self-made Cities: In search of sustainable solutions for informal settlements in the United Nations Economic Commission for Europe Region. Vol. 9. 2009, New York and Geneva: United Nations Publications.

13. Bobic, N., NEW BELGRADE AFTER 1999: Spatial violence as de-socialisation, deromanisation, and de-historisation. Architectural Theory Review, 2014. 19(3): p. 355-375.

14. Jovanović, M. and I. Ratkaj, Functional Metamorphosis of New Belgrade. disPThe Planning Review, 2014. 50(4): p. 54-65.

15. Waley, P., From modernist to market urbanism: the transformation of New Belgrade. Planning Perspectives, 2011. 26(2): p. 209-235.

16. Al-Hagla, K., Towards a sustainable neighborhood: The role of open spaces. Architectural Research, 2008. 2: p. 162-177.

17. Healey, P., The treatment of space and place in the new strategic spatial planning in Europe. International journal of urban and regional research, 2004. 28(1): p. 45-67.

18. Stanley, B.W., et al., Urban open spaces in historical perspective: A transdisciplinary typology and analysis. Urban Geography, 2012. 33(8): p. 1089-1117.

19. Agnew, J.A., Place and politics in modern Italy. 2002: University of Chicago Press.

20. Beatley, T. and K. Manning, The Ecology of Place. Planning for Environment, 1997.

21. Ward Thompson, C., Urban open space in the 21st century. Landscape and urban planning, 2002. 60(2): p. 59-72.

22. Jenerette, G.D., et al., Ecosystem services and urban heat riskscape moderation: water, green spaces, and social inequality in Phoenix, USA. Ecological Applications, 2011. 21(7): p. 2637-2651.

23. Tengberg, A., et al., Cultural ecosystem services provided by landscapes: assessment of heritage values and identity. Ecosystem Services, 2012. 2: p. 14-26.

24. Forsyth, A. and K. Crewe, New visions for suburbia: Reassessing aesthetics and place-making in modernism, imageability and new urbanism. Journal of Urban Design, 2009. 14(4): p. 415-438.

25. Madureira, A.M., Physical planning in place-making through design and image building. Journal of Housing and the Built Environment, 2013. 30(1): p. 157-172.

26. Norberg-Schulz, C., Concept of Place, in Architecture, Meaning and Place. Selected Essays. 1988, Rizzoli International Publications: New York, NY. p. 27-38.

27. Relph, E.C., Place and Placelessness. Research in Planning and Design, ed. A.J. Scott. Vol. 1. 2008, London: Pion. 156

28. Walker, J. and M. Cooper, Genealogies of resilience from systems ecology to the political economy of crisis adaptation. Security Dialogue, 2011. 42(2): p. 143-160.

29. Holston, J., Insurgent citizenship in an era of global urban peripheries. City \& Society, 2009. 21(2): p. 245-267.

30. Goheen, P.G., Public space and the geography of the modern city. Progress in Human Geography, 1998. 22(4): p. 479-496.

31. Chetkiewicz, C.-L.B., C.C. St. Clair, and M.S. Boyce, Corridors for conservation: integrating pattern and process. Annual Review of Ecology, Evolution, and Systematics, 2006: p. 317-342.

32. Colding, J., 'Ecological land-use complementation'for building resilience in urban ecosystems. Landscape and urban planning, 2007. 81(1): p. 46-55.

33. Villanueva, C., Community development and the futures of sustainable communities in the Philippines, in Sustainable global community in the information age: Vision from future studies. Praeger Studies on the 21st Century, Y. Kaoru, Editor. 1997: Praeger, CT.

34. Andrews, C.J., Analyzing Quality-of-Place. Environment and Planning B: Planning and Design, 2001. 28(2): p. 201-217.

35. Buttimer, A. and D. Seamon, The Human Experience of Space and Place. 1980: Croom Helm London.

36. Perrigo, T., Management of Heritage Places: The Path Towards Sustainability, in Registered Workshop. 2015, Heriatge Energized: National Trust Conference: Calgary, Alberta.

37. Palermo, P.C. and D. Ponzini, Place-Making and Urban Development : New 
Challenges For Contemporary Planning and Design. Regions and Cities. Vol. 83. 2014, New York, NY: Routledge.

38. Carmona, M., C. de Magalhães, and L. Hammond, Public Space: The Management Dimension. 2008, London; New York: Routledge.

39. Thompson, C.W., Urban open space in the 21st century. Landscape and urban planning, 2002.60(2): p. 59-72.

40. Yin, R.K., Applications of Case Study Research. 2nd ed. 2003, Thousand Oaks, $C A$ : Sage.

41. Walliman, N., Your research project, in Research Methods: The Basics. 2007, Sage Publications. p. 226-249.

42. Le Normand, B., Designing Tito's Capital: Urban Planning, Modernism, and Socialism. 2014, Pittsburgh, Pa.: University of Pittsburgh Press. 